\title{
VASCULAR FLORA OF E. C. HAFER PARK, EDMOND, OKLAHOMA
}

\author{
Gloria M. Caddell \\ Katie Christoffel \\ Carmen Esqueda \\ Alonna Smith \\ Department of Biology \\ University of Central Oklahoma \\ Edmond, OK 73007 \\ gcaddell@uco.edu
}

Keywords: floristic inventory, urban park, Cross Timbers, non-native, invasive

\begin{abstract}
E. C. Hafer Park is located on the western edge of the Cross Timbers ecoregion, in central Oklahoma within the City of Edmond. The park contains post oak-blackjack oak forest, tallgrass prairie, riparian forest, and areas developed for recreational activities. A vascular plant inventory conducted during 2013, 2015, 2016, and 2017 yielded 270 species in 190 genera and 65 families. The largest families were the Asteraceae (46 species), Poaceae (42), and Fabaceae (27). There were 96 annuals, four biennials, and 170 perennials. Sixty species $(22.2 \%)$ were not native to the United States. No rare species currently being tracked by the Oklahoma Natural Heritage Inventory were present. Compared to floristic inventories for other sites of similar size in Oklahoma, Hafer Park has a relatively high number of species. However, it also has a relatively high percentage of exotic species from other continents, some of which are invasive and are threatening the native forest, grassland, and riparian plant communities.
\end{abstract}

\section{INTRODUCTION}

Efforts to protect biodiversity often focus on large natural habitats outside of highly urbanized locations, but efforts should also be made to preserve and promote biodiversity in urban forests and other urban green spaces that have maintained relatively high levels of biodiversity including species of conservation concern (Alvey 2006). In a literature review of species richness in urban parks on five continents, Nielsen et al. (2013) found that those with a diversity of habitats and microhabitats can be biodiversity hotspots with large components of native species of all plant and animal groups. For vascular plants, however, urban parks often have a large percentage of exotic species, sometimes over 50\% (Nielsen et al. 2013).

Palmer et al. (1995) summarized the importance of floristic inventories in providing data for research on biodiversity, environmental impact assessment, and management decisions. The Floras of North America project (Palmer 2017) promotes the compilation of floras, emphasizing their importance as "baselines for understanding patterns of, and threats to, modern biodiversity".

We conducted a floristic inventory of E. C. Hafer Park, an urban park in central Oklahoma, from 2013 to 2017. Our 
objectives were to 1) document the vascular plant richness of a central Oklahoma urban park; 2) contribute to our knowledge of plant distributions in Oklahoma; 3) assess the threat that exotic species, i.e., from other continents, pose to the biodiversity of this urban park; and 4) provide a resource that can be used by the City of Edmond to conserve the biodiversity of Hafer Park and to educate the public.

\section{STUDY AREA}

E. C. Hafer Park is located in the City of Edmond, Oklahoma County, Oklahoma (T14N, R2W, SW1/4 of Sec 31). Latitudinal extent is from $35^{\circ} 38^{\prime} 17^{\prime \prime} \mathrm{N}$ to $35^{\circ} 38^{\prime} 44^{\prime \prime}$ $\mathrm{N}$, and longitudinal extent is from $97^{\circ} 27^{\prime} 6^{\prime \prime}$ $\mathrm{W}$ to $97^{\circ} 27^{\prime} 37^{\prime \prime} \mathrm{W}$. The park consists of approximately 49 hectares (=121 acres). Spring Creek flows west to east along the southern edge of the park. Elevation ranges from approximately $326 \mathrm{~m}$ to $345 \mathrm{~m}$. Soils are Stephenville-Darnell-Niotaze shallow, sandy and loamy soils that are moderately acidic and humus-poor, and occur on steep slopes up to 18\% (Carter and Gregory 2008).

The climate is continental. According to climate data for the past 15 years (20022016) from Mesonet stations in Oklahoma County (Oklahoma Climatological Survey 2017 b), average annual precipitation was $89.8 \mathrm{~cm}$. The mean annual temperature for 2002-2016 was $16.1^{\circ} \mathrm{C}$, with daily average temperatures ranging from $3.9^{\circ} \mathrm{C}$ in January to $27.8^{\circ} \mathrm{C}$ in July. Temperatures ranged from an average low temperature of $-1.7^{\circ} \mathrm{C}$ in January to an average daytime high of $33.3^{\circ} \mathrm{C}$ in July. Average wind speed was 8 mph.

The climate averages for the past 15 years differ somewhat from longer-term historical trends. For example, from 20022016 spring and summer had the highest average precipitation, but historically fall and spring have been the wettest seasons (Oklahoma Climatological Survey 2017a).
Annual precipitation for Oklahoma County varied considerably for the four years during which this vascular plant survey was conducted, ranging from $75.4 \mathrm{~cm}$ to $131.3 \mathrm{~cm}$.

E. C. Hafer Park is in the Central RedBed Plains physiographic province, in which "Permian red shales and sandstone form gently rolling hills and broad, flat plains" (Curtis et al. 2008). It is on the western edge of the Cross Timbers ecoregion (Oklahoma Forestry Services 2017) and is in the Northern Cross Timbers Level III Ecoregion (Environmental Protection Agency 2017). The dominant potential vegetation is post oak-blackjack oak woodland (Duck and Fletcher 1943).

King and Cheek (2015) documented the land-use history of the site. From the early 1900 s to the 1940s, historical documents indicate that it was privately owned and farmed. From 1952 to 1972, a portion of the site housed a sewage treatment facility operated by the City of Edmond. Following decommissioning of the facility in 1972 and the acquisition of additional small tracts of land, the site was commissioned as E. C. Hafer Park in 1979. Paved trails, playgrounds, picnic areas, and pavilions have been constructed, but the eastern half of the park is primarily post oak-blackjack oak forest with tallgrass prairie in the northeast corner.

\section{METHODS}

We surveyed the park during the growing seasons (March through October) of 2013, 2015, 2016, and 2017. During those years, we visited the site 23 times, with 6 collecting dates in the spring, 10 in the summer, and 7 in the fall. We recorded the vascular plant species encountered and collected voucher specimens. We collected non-native and exotic species only from naturalized populations, excluding cultivated species in flower beds, picnic areas, playgrounds, etc. A few species were 
identified by sight and documented only by photographs because of their rarity at the site or because the steep slope of Spring Creek made a collection impossible.

References used for specimen identification included Great Plains Flora Association (1986), Diggs et al. (1999), Yatskievyich (1999), Barkworth et al. (2007), and Tyrl et al. (2015). In addition to our collections, we searched the University of Central Oklahoma Herbarium (CSU) database and added a few previously collected species from the park. Specimens were identified only to the species level.

The organization of taxa in our species list is based on Angiosperm Phylogeny Group (APG III) recommendations (Stevens 2017). Nomenclature follows the Integrated Taxonomic Information System (2017). The PLANTS Database (USDA NRCS 2017) was used for common names and to determine whether each species was native to the United States, its duration (annual, biennial, or perennial), and its growth form (forb, graminoid, shrub, tree, or woody vine). If duration varied or if more than one growth form was listed in the PLANTS Database, the duration and growth form listed for Oklahoma by Taylor and Taylor (1994) was used. Voucher specimens were deposited in the University of Central Oklahoma (CSU) Herbarium. Our reporting of site location and geography, taxonomy, voucher specimens, botanical effort, exotic species, taxonomic list, and summary table follows recommendations by Palmer and Richardson (2012) for published floras. An "invasive species", as defined by Executive Order 13112, is one that is " 1 ) non-native (or alien) to the ecosystem under consideration and 2) whose introduction causes or is likely to cause economic or environmental harm or harm to human health" (USDA National Agricultural Library 2017).

Table 1 Summary of floristic collections from E. C. Hafer Park in Edmond, Oklahoma*

\begin{tabular}{lccccc}
\hline $\begin{array}{c}\text { Taxonomic } \\
\text { Group }\end{array}$ & Families & Genera & Species & $\begin{array}{c}\text { Native } \\
\text { spp. }\end{array}$ & $\begin{array}{c}\text { Non-native } \\
\text { spp. }\end{array}$ \\
\hline $\begin{array}{l}\text { Monilophyta } \\
\text { Pinophyta }\end{array}$ & 1 & 1 & 1 & 1 & 0 \\
Magnoliophyta & 1 & 1 & 1 & 1 & 0 \\
Eudicots & 55 & 146 & 206 & 162 & 44 \\
Monocots & 8 & 42 & 62 & 46 & 16 \\
\hline
\end{tabular}

* Table format follows Palmer (1995) 


\section{RESULTS AND DISCUSSION}

We identified 270 species in 190 genera and 65 families (Table 1; Appendix). These included one monilophyte, one gymnosperm, 206 eudicots, and 62 monocots. Species in the Asteraceae (46), Poaceae (42), and Fabaceae (27) far outnumbered those in other families. Only six other families were represented by more than five species: Euphorbiaceae (9), Cyperaceae (8), Rosaceae (8), Rubiaceae (7), Plantaginaceae (6), and Polygonaceae (6). The largest genera, each with five species, were Quercus, Solidago, and Bromus. Ninety-six species $(35.5 \%)$ were annuals, four $(1.5 \%)$ were biennials, and $170(63 \%)$ were perennials. Thirty-eight species were trees, 12 were shrubs, and 10 were woody vines. There were 157 forbs and 53 graminoids.

No rare species tracked by the Oklahoma Natural Heritage Inventory (2017) were present. Sixty species $(22.2 \%)$ in 26 families were not native to the United States. These included 13 species of Poaceae, 10 species of Fabaceae, and 5 species of Asteraceae. All but one nonnative species (Torilis arvensis) were exotic to North America. Eight exotic species (Albizia julibrissin, Bromus japonicus, Bromus tectorum, Lespedeza cuneata, Ligustrum sinense, Lonicera japonica, Rosa multiflora, Sorghum balepense) are listed as Oklahoma Problem Species by the Oklahoma Invasive Plants Council (2017). Five of these species (B. tectorum, L. cuneata, L. sinense, L. japonica, $S$. balepense) and one native species (Juniperus virginiana) are on the OKIPC's "Dirty Dozen" list of the worst invasive species in the state. Four species (Erodium cicutarium, Lonicera maackii, Melilotus officinalis, Pyrus calleryana) are on the Oklahoma Watch List, and an additional 19 species are listed as problem species in states bordering Oklahoma (Oklahoma Invasive Plants Council 2017). Other species may become problems in the future. For example, Koelreuteria paniculata, Nandina domestica, and
Pistacia chinensis were found in the forest, and these cultivated species are considered invasive in Texas and other southeastern states (Texas Invasives 2017).

The major plant communities at Hafer Park and brief descriptions of common species are as follows:

\section{Quercus stellata-Quercus} matilandica/Schizachyrium scoparium woodland association (Hoagland 2000)

Post oak/blackjack oak woodland is the predominant vegetation association in the park. Common species included Celtis spp., Cornus drummondii, Juniperus virginiana, Morus rubra, Quercus mueblenbergii, Sideroxylon lanuginosum, Symphoricarpos orbiculatus, and Ulmus spp. Fraxinus pennsylvanica, Prunus mexicana, Quercus shumardii, and Viburnum rufidulum were occasionally encountered. Exotic woody plants found in this community included Ligustrum sinense, Lonicera maackii, Pyrus calleryana, and Rosa multiflora.

\section{Schizachytium scoparium-} Sorghastrum nutans herbaceous association (Hoagland 2000)

This tallgrass prairie community was found in the northeast corner of the park. Commonly encountered species included Acacia angustissima, Ambrosia psilostachya, Asclepias verticillata, Asclepias viridis, Boutelona spp., Chamaecrista fasciculata, Coreopsis tinctoria, Dichanthelium spp., Eragrostis spp., Gaillardia aestivalis, Lespedera spp., Liatris punctata, Panicum virgatum, Psoralidium tenuiflorum, Sabatia campestris, Solidago spp., Symphyotrichum ericoides, and Xanthisma texanum. Rhus glabra has spread into much of this area. The invasive native Juniperus virginiana and the invasive exotic Lespedeza cuneata are threatening this community.

\section{Riparian forest}

Riparian forest was found on the steep banks of Spring Creek. Common woody species included Catalpa speciosa, Celtis spp., 
Cercis canadensis, Cornus drummondii, Juglans nigra, Juniperus virginiana, Morus rubra, Populus deltoides, Salix nigra, Sapindus saponaria, Ulmus americana, and Ulmus rubra. Quercus macrocarpa, Q. mueblenbergii, Acer negundo, Gymnocladus dioicus, and Equisetum laevigatum were occasionally encountered. Common vines included Cocculus carolinus, Parthenocissus quinquefolia, Smilax spp., and Toxicodendron radicans. Exotic woody plants found in this community included Albizia julibrissin and Ulmus parvifolia.

\section{Disturbed areas}

This type of vegetation was found predominately in mowed lawns around picnic areas and playgrounds and along paved trails. Common species included Ambrosia trifida, Arenaria serpyllifolia, Bromus spp., Cerastium pumilum, Cruciata pedemontana, Cynodon dactylon, Erodium cicutarium, Geranium pusillum, Lamium amplexicaule, Lonicera japonica, Medicago lupulina, Scleranthus annuus, Stellaria media, Sherardia arvensis, Sorghum balepense, Trifolium repens, and Veronica spp. Disturbed areas of Spring Creek have been invaded by exotic species such as Phragmites australis, Parthenium hysterophorus, and Clematis terniflora.

A comparison with the species-area relationship for 59 Oklahoma floras published by Palmer (2007) indicates the flora of Hafer Park is among the richest for areas of a similar size. However, of all the floras listed, only one (Vance Air Force Base) had a higher proportion of non-native species (46.8\%) than Hafer Park $(22.2 \%)$. The next highest is for a checklist of plants in Cleveland County, at 17.5\%. The percentage of non-native taxa from grassland-dominated sites (Buthod and Hoagland 2016) in Oklahoma ranged from $8.8 \%$ to $15 \%$. The percentage of non-native taxa for Alabaster Caverns State Park, a heavily-visited park in the Cimarron Gypsum Hills of Woodward County, Oklahoma, was 15.3\% (Caddell and Rice
2012). Inventories of natural areas in Oklahoma generally exclude cultivated plants that have not become naturalized, and those plants have been excluded in the inventory reported here. However, the proportion of non-native species for Hafer Park would be much higher if those plants were included.

This inventory indicates that Hafer Park has a rich vascular plant community, in spite of the development of large portions for recreational use. It has a variety of habitats that support high plant diversity within the rapidly developing City of Edmond.

However, the native plant communities at Hafer Park are threatened by an increase in exotic, invasive plants that are already reported as invasive within the state, as well as perhaps by others that are considered invasive in adjacent states. The diversity of the understory of the post oak-blackjack oak forest is being threatened particularly by the invasion of Chinese privet (Ligustrum sinense), and the tallgrass prairie in the northeast corner of the park is being threatened particularly by encroachment of the native invader eastern red cedar (Juniperus virginiana) and by the exotic invasive Lespedeza cuneata.

\section{ACKNOWLEDGMENTS}

We thank the City of Edmond Parks and Recreation Department for permission to conduct this study. We also thank Shahang Derakhshan, Rachel Cotts, and Aaron Kidd for assistance with plant collections and Madelynne Short and Brandi Easton for assistance with mounting specimens. Dr. Johnnie Gentry identified Rubus aboriginum specimens.

\section{LITERATURE CITED}

Alvey, A.A. 2006. Promoting and preserving biodiversity in the urban forest. Urban Forestry and Urban Greening 5:195-201. http://www.sciencedirect.com 
Barkworth, M.E., L.K. Anderton, K.M. Capels, S. Long, and M.B. Piep, eds. 2007. Manual of Grasses for North America. Logan (UT): Intermountain Herbarium and Utah State University Press.

Buthod, A.K. and B.W. Hoagland. 2016. A floristic inventory of the University of Oklahoma's Kessler Atmospheric and Ecological Field Station, McClain County, Oklahoma. Oklahoma Native Plant Record 16:45-63.

Caddell, G.M. and K.D. Rice. 2012. Vascular flora of Alabaster Caverns State Park, Cimarron Gypsum Hills, Woodward County, Oklahoma. Oklahoma Native Plant Record 12:43-62.

Carter, B.J. and M.S. Gregory. 2008. Soil map of Oklahoma. In: Johnson, K.S. and K.V. Luza, eds. Earth Sciences and Mineral Resources of Oklahoma.

Educational Publication 9. Norman $(\mathrm{OK})$ : Oklahoma Geological Survey. http://www.ogs.ou.edu/pubsscanned/ EP9 All.pdf

Curtis, N.M., W.E. Ham, and K.S. Johnson. 2008. Geomorphic provinces of Oklahoma. In: Johnson, K.S. and K.V. Luza, eds. Earth Sciences and Mineral Resources of Oklaboma. Educational Publication 9. Norman (OK): Oklahoma Geological Survey. http://www.ogs.ou.edu/pubsscanned/ EP9 All.pdf

Diggs, G.M., B.L. Lipscomb, and R.J. O'Kennon. 1999. Shinners and Mabler's Illustrated Flora of North Central Texas. Fort Worth (TX): Botanical Research Institute of Texas.

Duck, L.G. and J.D. Fletcher. 1943. A game type map of Oklahoma. In: A Survey of the Game and Furbearing Animals of Oklahoma. Oklahoma City (OK): Oklahoma Department of Wildlife Conservation. http://biosurvey.ou.edu/download/duc kflt/dfmap.gif
Environmental Protection Agency. 2017. Level III and Level IV Ecoregions of Oklahoma. http://www.epa.gov

Great Plains Flora Association. 1986. Flora of the Great Plains. Lawrence (KS): University of Kansas.

Hoagland, B.W. 2000. The vegetation of Oklahoma: A classification for landscape mapping and conservation planning. Southwestern Naturalist 45:385420.

Integrated Taxonomic Information System (ITIS). 2017. http://www.itis.gov (October 2017).

King, C.B. and J. Cheek. 2015. Dendroecology, forest composition, and land-use history of a suburban Cross Timbers forest in central Oklahoma. Urban Naturalist 6:1-20.

Nielsen, A.B., M. van den Bosch, S. Maruthaveeran, and C. van den Bosch. 2013. Species richness in urban parks and its drivers: A review of empirical evidence. Urban Ecosystems 17:305-327. New York: Springer. https://link.springer.com/article/10.10 07/s11252-013-0316-1

Oklahoma Climatological Survey. 2017a. The Climate of Oklahoma County. http://climate.ok.gov/index.php/climat e/county climate by county/oklahoma

Oklahoma Climatological Survey. 2017b. Mesonet Long-Term Averages - Maps. http://www.mesonet.org/index.php/w eather/mesonet averages maps

Oklahoma Forestry Services. 2017. The Ecoregions of Oklahoma. http://www.forestry.ok.gov

Oklahoma Invasive Plants Council. 2017. Oklahoma Invasives. https://www.okinvasives.org (16 September 2017).

Oklahoma Natural Heritage Inventory. 2017. Oklahoma Natural Heritage Inventory Plant Tracking List. http://www.biosurvey.ou.edu/downloa d/publications/onhi plants tracking 5 2012.pdf (5 December 2017). 
Palmer, M.W. 2007. Vascular plants checklists from Oklahoma. Oklahoma Native Plant Record 7:67-77.

Palmer, M.W. 2017. Floras of North America Project. http://botany.okstate.edu/floras/

Palmer, M.W. and J.C. Richardson. 2012. Biodiversity data in the information age: Do $21^{\text {st }}$ century floras make the grade? Castanea 77(1): 46-59.

Palmer, M.W., G.L. Wade, and P.R. Neal. 1995. Standards for the writing of floras. Bioscience 45:339-345.

Stevens, P.F. (2001 onwards). Angiosperm Phylogeny Website. Version 14, July 2017. http://www.mobot.org/MOBOT/resea rch/APweb/

Taylor, R.J. and C.E.S. Taylor. 1994. An Annotated List of the Ferns, Fern Allies, Gymnosperms and Flowering Plants of Oklahoma. Durant (OK): Self-published.

Texas Invasives. 2017. Invasives Database. http://texasinvasives.org (8 October 2017).
Tyrl, R.J., S.C. Barber, P. Buck, W.J. Elisens, J.R. Estes, P. Folley, L.K. Magrath, C.L. Murray, A.K. Ryburn, B.A. Smith, C.E.S. Taylor, R.A. Thompson, J.B. Walker, and L.E. Watson. 2010, 2015. Flora of Oklahoma: Keys and Descriptions. Oklahoma City (OK): Flora Oklahoma Incorporated.

USDA National Agricultural Library. 2017. National Invasive Species Information Center. https://www.invasivespeciesinfo.gov/w hatis.shtml

USDA NRCS. 2017. The PLANTS

Database.http://plants.usda.gov National Plant Data Team, Greensboro, NC 27401-4901 USA (30 November 2017).

Yatskievych, G. 1999. Steyermark's Flora of Missouri. Volume 1, revised edition. St. Louis (MO): Missouri Department of Conservation and Missouri Botanical Garden Press. 


\section{APPENDIX}

\section{Vascular Plant Species from E. C. Hafer Park, Edmond, Oklahoma}

Annotated species list with organization based on Angiosperm Phylogeny Group (APG III) recommendations (Stevens 2017). Nomenclature is based on ITIS (2017), and common names are from the USDA PLANTS Database (USDA NRCS 2017). Duration ( $A=a n n u a l, B=b i e n n i a l$, $\mathrm{P}=$ perennial), growth form ( $\mathrm{F}=$ forb, $\mathrm{G}=$ graminoid, $\mathrm{S}=$ shrub, $\mathrm{T}=$ tree, $\mathrm{V}=$ =woody vine), and collection numbers follow species name. Duration, nativity, and growth form are from the USDA PLANTS Database (USDA NRCS 2017). If duration varied or if more than one growth form was listed in the PLANTS Database, the duration and growth form listed for Oklahoma by Taylor and Taylor (1994) was used. Non-native species to the United States are indicated with an asterisk ( $\left.{ }^{*}\right)$. Collectors are AK= Aaron Kidd, AP= Alonna Price Smith, $\mathrm{CC}=$ Carmen Cowo Esqueda, GC=Gloria Caddell, HU=Hitomi Ushio, KC= Katie Christoffel, RC= Rachel Cotts, SD= Shahang Derakhshan, TW=T. Williams, and YS=Yukiko Shimoda. Voucher specimens were deposited in the University of Central Oklahoma Herbarium (CSU).

\section{MONILOPHYTA}

Equisetaceae

Equisetum laevigatum A. Braun (smooth horsetail) - P; F; GC1315

\section{GYMNOSPERMS/PINOPHYTA}

\section{Cupressaceae}

Juniperus virginiana L. (eastern redcedar) - P; T; AP105, CC50

\section{ANGIOSPERMS/MAGNOLIOPHYTA EUDICOTS}

\section{Acanthaceae}

Dicliptera brachiata (Pursh) Spreng. (branched foldwing) - A; F; GC1316

Ruellia humilis Nutt. (fringeleaf wild petunia) - P; F; AP127, KC88

\section{Adoxaceae}

Viburnum rufidulum Raf. (rusty blackhaw) - P; T, S; KC91

\section{Amaranthaceae}

Amaranthus arenicola I.M. Johnst. (sandhill amaranth) - A; F; KC115, KC116

Froelichia floridana (Nutt.) Moq. (plains snakecotton) - A; F; AP107

\section{Anacardiaceae}

*Pistacia chinensis Bunge (Chinese pistache) - P; T; KC123

Rhus copallinum L. (winged sumac) - P; S; AP96, CC67

Rhus glabra L. (smooth sumac) - P; S; AP124, SD67

Toxicodendron radicans (L.) Kuntze (eastern poison ivy) - P; V; KC69

\section{Apiaceae}

Chaerophyllum tainturieri Hook. (hairyfruit chervil) - A; F; GC 1306

Sanicula canadensis L. (Canadian blacksnakeroot) - B; F; AP75

${ }^{\star}$ Torilis arvensis (Huds.) Link (spreading hedgeparsley) - A; F; AP93, KC68 


\section{Apocynaceae}

Apocynum cannabinum L. (Indianhemp) - P; F; AP122

Asclepias verticillata L. (whorled milkweed) - P; F; AP109

Asclepias viridis Walter (green antelopehorn) - P; F; RC74

\section{Asteraceae}

Achillea millefolium L. (common yarrow) - P; F; AP67

Ambrosia psilostachya DC. (Cuman ragweed) - P; F; CC49

Ambrosia trifida L. (great ragweed) - A; F; KC87

Amphiachyris dracunculoides (DC.) Nutt. (prairie broomweed) - A; F; SD69

Antennaria parlinii Fernald (Parlin's pussytoes) - P; F; KC139

Artemisia ludoviciana Nutt. (white sagebrush) - P; F; GC1300

Bidens bipinnata L. (Spanish needles) - A; F; KC89

Bradburia pilosa (Nutt.) Semple (soft goldenaster) - A; F; AP92, CC52, CC53

Cirsium altissimum (L.) Hill (tall thistle) - B; F; KC39

Cirsium undulatum (Nutt.) Spreng. (wavyleaf thistle) - P; F; AP120

Conyza canadensis (L.) Cronquist (Canadian horseweed) - A; F; AK1

Coreopsis tinctoria Nutt. (golden tickseed) - A; F; AP94

${ }^{*}$ Cosmos sulphureus Cav. (sulphur cosmos) - A; F; KC80

Diaperia prolifera (Nutt. ex DC.) Nutt. (bighead pygmycudweed) - A; F; RC59

Diaperia verna (Raf.) Morefield (spring pygmycudweed) - A; F; GC1301

Eclipta prostrata (L.) L. (false daisy) - A; F; KC150

Elephantopus carolinianus Raeusch (Carolina elephantsfoot) - P; F; KC58

Erigeron strigosus Muhl. ex Willd. (prairie fleabane) - A; F; AP90

Gaillardia aestivalis (Walter) H. Rock (lanceleaf blanketflower) - P; F; AP99

Gamochaeta argyrinea G. L. Nesom (silvery everlasting) - A; F; AP53

Gamochaeta purpurea (L.) Cabrera (spoonleaf purple everlasting) - P; F; GC1302

Grindelia ciliata (Nutt.) Spreng. (Spanish gold) - A; F; KC95

Helianthus annuus L. (common sunflower) - A; F; KC42, KC94

Helianthus mollis Lam. (ashy sunflower) - P; F; KC40

Heterotheca subaxillaris (Lam.) Britton \& Rusby (camphorweed) - A; F; SD60, KC149

Lactuca ludoviciana (Nutt.) Riddell (biannual lettuce) - B; F; AK3

*Lactuca serriola L. (prickly lettuce) - A; F; AP113

Liatris punctata Hook. (dotted blazing star) - P; F; SD72, GC1317

${ }^{*}$ Parthenium hysterophorus L. (Santa Maria feverfew) - A; F; KC148

Pluchea camphorata (L.) DC. (camphor pluchea) - P; F; KC76

Pseudognaphalium obtusifolium (L.) Hilliard \& B.L. Burtt (rabbit-tobacco) - A; F; KC112

Pyrrhopappus grandiflorus (Nutt.) Nutt. (tuberous desert-chicory) - P; F; RC57

Solidago canadensis L. (Canada goldenrod) - P; F; KC102

Solidago missouriensis Nutt. (Missouri goldenrod) - P; F; KC77

Solidago nemoralis Aiton (gray goldenrod) - P; F; CC48

Solidago rigida L. (stiff goldenrod) - P; F; CC42

Solidago speciosa Nutt. (showy goldenrod) - P; F; CC41

Symphyotrichum drummondii (Lindl.) G.L. Nesom (Drummond's aster) - P; F; CC70, KC78, KC85

Symphyotrichum ericoides (L.) G.L. Nesom (white heath aster) - P; F; CC44

Symphyotrichum subulatum (Michx.) G.L. Nesom (eastern annual saltmarsh aster) - A; F; KC99, KC147, SD79 
*Taraxacum officinale F.H. Wigg. (common dandelion) - P; F; AP64

Thelesperma filifolium (Hook.) A. Gray (stiff greenthread) - P; F; AP108

*Tragopogon dubius Scop. (yellow salsify) - A; F; AP104

Verbesina virginica L. (white crownbeard) - P; F; SD71

Vernonia baldwinii Torr. (Baldwin's ironweed) - P; F; KC41

Xanthisma texanum DC. (Texas sleepydaisy) - A; F; SD77

\section{Berberidaceae}

*Nandina domestica Thunb. (sacred bamboo) - P; S; GC1320, KC83, SD75

\section{Bignoniaceae}

Campsis radicans (L.) Seem. ex Bureau (trumpet creeper) - P; V; GC 1322

Catalpa speciosa (Warder) Warder ex Engelm. (northern catalpa) - P; T; RC38, KC101, KC163

\section{Boraginaceae}

Myosotis verna Nutt. (spring forget-me-not) - A; F; GC1291

\section{Brassicaceae}

*Capsella bursa-pastoris (L.) Medik. (shepherd's purse) - A; F; KC127

Lepidium virginicum L. (Virginia pepperweed) - A; F; AP71, RC48, GC1294

\section{Cactaceae}

Opuntia humifusa (Raf.) Raf. (devil's-tongue) - P; S; GC1319

\section{Campanulaceae}

Triodanis perfoliata (L.) Nieuwl. (clasping Venus' looking glass) - A; F; RC42

\section{Cannabaceae}

Celtis laevigata Willd. (sugarberry) - P; T; RC77

Celtis occidentalis L. (common hackberry) - P; T; KC59

Celtis reticulata Torr. (netleaf hackberry) - P; T; AP65, KC37, KC84

\section{Caprifoliaceae}

*Lonicera japonica Thunb. (Japanese honeysuckle) - P; V; SD66, KC162

*Lonicera maackii (Rupr.) Herder (Amur honeysuckle) - P; S; GC1285

Lonicera sempervirens L. (trumpet honeysuckle) - P; V; YS31

Symphoricarpos orbiculatus Moench (coralberry) - P; S; SD63

\section{Caryophyllaceae}

${ }^{*}$ Arenaria serpyllifolia L. (thymeleaf sandwort) - A; F; AP74, RC82

${ }^{*}$ Cerastium pumilum W. Curtis (European chickweed) - A; F; RC41, GC1292

*Scleranthus annuus L. (German knotgrass) - A; F; GC1304

*Stellaria media (L.) Vill. (common chickweed) - A; F; RC45

\section{Celastraceae}

*Euonymus europaeus L. (European spindletree) - P; S; KC57 


\section{Cistaceae}

Lechea tenuifolia Michx. (narrowleaf pinweed) - P; F; AP103, GC1278, KC61

\section{Cornaceae}

Cornus drummondii C.A. Mey. (roughleaf dogwood) - P; T; AP58, CC64, RC56

\section{Cucurbitaceae}

Melothria pendula L. (Guadeloupe cucumber) - P; F; KC109

\section{Ebenaceae}

Diospyros virginiana L. (common persimmon) - P; T; KC50

\section{Euphorbiaceae}

Acalypha gracilens A. Gray (slender threeseed mercury) - A; F; KC46, SD58

Acalypha ostryifolia Riddell (pineland threeseed mercury) - A; F; KC117

Croton glandulosus L. (vente conmigo) - A; F; KC48, KC75

Croton lindheimerianus Scheele (threeseed croton) - A; F; AP110

Croton monanthogynus Michx. (prairie tea) - A; F; SD78

Euphorbia corollata L. (flowering spurge) - P; F; CC62

Euphorbia dentata Michx. (toothed spurge) - A; F; KC47

Euphorbia maculata L. (spotted sandmat) - A; F; SD64, KC49

Euphorbia nutans Lag. (eyebane) - A; F; KC97

\section{Fabaceae}

Acacia angustissima (Mill.) Kuntze (prairie acacia) - P; F; CC45

Acmispon americanus (Nutt.) Rydb. (American bird's-foot trefoil) - A; F; RC73

*Albizia julibrissin Durazz. (silktree) - P; T; KC51, KC105

Cercis canadensis L. (eastern redbud) - P; T; AP66, SD57, KC137

Chamaecrista fasciculata (Michx.) Greene (partridge pea) - A; F; AP102, CC43

Desmanthus illinoensis (Michx.) MacMill. ex B.L. Rob. \& Fernald (Illinois bundleflower) - P; F; AP97

Desmodium paniculatum (L.) DC. (panicledleaf ticktrefoil) - P; F; KC153

Desmodium sessilifolium (Torr.) Torr. \& A. Gray (sessileleaf ticktrefoil) - P; F; CC59

Desmodium viridiflorum (L.) DC. (velvetleaf ticktrefoil) - P; F; KC141

Galactia regularis (L.) Britton, Sterns \& Poggenb. (eastern milkpea) - P; F; KC66, AP131

Gleditsia tricanthos L. (honeylocust) - P; T; GC 1321

Gymnocladus dioicus (L.) K. Koch (Kentucky coffeetree) - P; T; GC1283

*Kummerowia stipulacea (Maxim.) Makino (Korean clover) - A; F; KC152

Lespedeza capitata Michx. (roundhead lespedeza) - P; F; CC55

*Lespedeza cuneata (Dum. Cours.) G. Don (sericea lespedeza) - P; F; SD74

Lespedeza stuevei Nutt. (tall lespedeza) - P; F; KC55

Lespedeza virginica (L.) Britton (slender lespedeza) - P; F; CC46

*Medicago lupulina L. (black medick) - A; F; RC47

*Medicago minima (L.) L. ex Bartal. (little bur-clover) - A; F; RC46

*Melilotus albus Medik. (white sweet clover) - A; F

*Melilotus officinalis (L.) Lam. (yellow sweet clover) - A; F; GC1280

Psoralidium tenuiflorum (Pursh) Rydb. (slimflower scurf pea) - P; F; AP100

Robinia pseudoacacia L. (black locust) - P; T; KC98 
Strophostyles helvola (L.) Elliott (amberique-bean) - A; F; AK7

*Trifolium dubium Sibth. (suckling clover) - A; F; AP56

*Trifolium repens L. (white clover) - P; F; RC53, KC157

*Vicia sativa L. (garden vetch) - A; F; GC1295

\section{Fagaceae}

Quercus macrocarpa Michx. (bur oak) - P; T; KC70

Quercus marilandica Munchh. (blackjack oak) - P; T; CC66

Quercus muehlenbergii Engelm. (chinquapin oak) - P; T; SD56

Quercus shumardii Buckley (Shumard's oak) - P; T; KC90

Quercus stellata Wangenh. (post oak) - P; T; CC68

\section{Gentianaceae}

Sabatia campestris Nutt. (Texas star) - A; F; AP128

\section{Geraniaceae}

*Erodium cicutarium (L.) L'Hér ex Aiton (redstem stork's bill) - A; F; AP63

*Geranium pusillum L. (small geranium) - A; F; RC40, GC1297

Geranium texanum (Trel.) A. Heller (Texas geranium) - A; F; GC1307

\section{Juglandaceae}

Carya illinoinensis (Wangenh.) K. Koch (pecan) - P; T; KC93

Juglans nigra L. (black walnut) - P; T; RC78

\section{Lamiaceae}

*Lamium amplexicaule L. (henbit deadnettle) - A; F; KC126

Monarda citriodora Cerv. ex Lag. (lemon beebalm) - A; F; AP98

Scutellaria parvula Michx. (small skullcap) - P; F; GC1298

Teucrium canadense L. (Canada germander) - P; F; AP129

\section{Malvaceae}

Callirhoe involucrata (Torr. \& A. Gray) A. Gray (purple poppymallow) - P; F; KC154

*Hibiscus trionum L. (flower of an hour) - A; $F$

\section{Menispermaceae}

Cocculus carolinus (L.) DC. (Carolina coralbead) - P; F; AP119, KC82

\section{Molluginaceae}

Mollugo verticillata L. (green carpetweed) - A; F; KC110

\section{Montiaceae}

Phemeranthus parviflorus (Nutt.) Kiger (sunbright) - P; F; GC1279

\section{Moraceae}

*Morus alba L. (white mulberry) - P; T; KC124

Morus rubra L. (red mulberry) - P; T; SD65 


\section{Nyctaginaceae}

Mirabilis albida (Walter) Heimerl (white four o'clock) - P; F; AP130

*Mirabilis jalapa L. (marvel of Peru) - P; F; KC114

Mirabilis nyctaginea (Michx.) MacMill. (heartleaf four o'clock) - P; F; GC1296

\section{Oleaceae}

Fraxinus pennsylvanica Marsh. (green ash) - P; T; KC65, KC106

*Ligustrum sinense Lour. (Chinese privet) - P; S; AP91, SD59, GC1299

\section{Onagraceae}

Ludwigia alternifolia L. (seedbox) - P; F; AP126

Oenothera biennis L. (common evening primrose) - B; F; KC108

Oenothera curtiflora W.L. Wagner \& Hoch (velvetweed) - A; F

Oenothera laciniata Hill (cutleaf evening primrose) - P; F; AP69

\section{Oxalidaceae}

Oxalis dillenii Jacq. (slender yellow woodsorrel) - P; F; AP54, RC36

Oxalis violacea L. (violet woodsorrel) - P; F

\section{Passifloraceae}

Passiflora lutea L. (yellow passionflower) - P; F; KC38

\section{Phytolaccaceae}

Phytolacca americana L. (American pokeweed) - P; F; AP123

\section{Plantaginaceae}

Plantago aristata Michx. (largebracted plantain) - A; F; AP76

Plantago patagonica Jacq. (woolly plantain) - A; F; RC64, KC161

Plantago virginica L. (Virginia plantain) - A; F; RC39, AP57, GC1290

*Veronica arvensis L. (corn speedwell) - A; F; GC1293, KC155

*Veronica hederifolia L. (ivyleaf speedwell) - A; F; KC138

*Veronica polita Fr. (gray field speedwell) - A; F; KC132

\section{Polygonaceae}

Fallopia scandens (L.) Holub (climbing false buckwheat) - P; F; GC1313

Persicaria bicornis (Raf.) Nieuwl (Pennsylvania smartweed) - A; F; KC100

Persicaria lapathifolia (L.) Gray (curlytop knotweed) - A; F; KC118

Persicaria virginiana (L.) Gaertn. (jumpseed) - P; F; KC119

*Polygonum aviculare L. (prostrate knotweed) - A; F; KC92

Rumex hastatulus Baldwin (heartwing sorrel) - P; F; AP62, RC63

\section{Portulacaceae}

Portulaca pilosa L. (kiss me quick) - A; F; GC1286

\section{Ranunculaceae}

${ }^{\star}$ Clematis terniflora DC. (sweet autumn virginsbower) - P; V; KC107

Ranunculus abortivus L. (littleleaf buttercup) - P; F 


\section{Rosaceae}

Geum canadense Jacq. (white avens) - P; F; GC1282, KC142

Prunus angustifolia Marshall (Chickasaw plum) - P; S; KC140

Prunus gracilis Engelm. \& A. Gray (Oklahoma plum) - P; S; RC75, AP121

Prunus mexicana S. Watson (Mexican plum) - P; T; KC134

Prunus virginiana L. (chokecherry) - P; T; YS30

${ }^{*}$ Pyrus calleryana Decne. (Callery pear) - P; T; KC72

${ }^{\star}$ Rosa multiflora Thunb. (multiflora rose) - P; V; KC71

Rubus aboriginum Rydb. (garden dewberry) - P; S; HU32, YS32

\section{Rubiaceae}

${ }^{*}$ Cruciata pedemontana (Bellardi) Ehrend. (piedmont bedstraw) - A; F; RC43, RC44

Diodella teres (Walter) Small (poorjoe) - A; F; CC54

Galium aparine L. (stickywilly) - A; F; GC1288

Galium circaezans Michx. (licorice bedstraw) - P; F; AP95, RC80

Galium pilosum Aiton (hairy bedstraw) - P; F; AP68

Houstonia pusilla Schoepf (tiny bluet) - A; F; KC131, GC1289

*Sherardia arvensis L. (blue fieldmadder) - A; F; AP73

\section{Rutaceae}

Zanthoxylum americanum Mill. (common pricklyash) - P; T; AP125, KC56, KC135

\section{Salicaceae}

Populus deltoides W. Bartram ex Marshall (eastern cottonwood) - P; T; KC52, KC96

Salix nigra Marshall (black willow) - P; T; RC58

\section{Santalaceae}

Phoradendron serotinum (Raf.) M.C. Johnst. (oak mistletoe) - P; S; KC125

\section{Sapindaceae}

Acer negundo L. (boxelder) - P; T

Acer saccharinum L. (silver maple) - P; T; KC122

*Koelreuteria paniculata Laxm. (goldenrain tree) - P; T; RC81

Sapindus saponaria L. (western soapberry) - P; T; KC44, KC62, KC79

\section{Sapotaceae}

Sideroxylon lanuginosum Michx. (gum bully) - P; T; SD53

\section{Solanaceae}

Solanum dimidiatum Raf. (western horsenettle) - P; F; TW46

Solanum elaeagnifolium Cav. (silverleaf nightshade) - P; F; KC103

Solanum ptycanthum Dunal (West Indian nightshade) - A; F; KC113, KC120

\section{Ulmaceae}

Ulmus americana L. (American elm) - P; T; RC35, SD54, SD55, KC128

*Ulmus parvifolia Jacq. (Chinese elm) - P; T; GC1314

Ulmus rubra Muhl. (slippery elm) - P; T; CC63 


\section{Urticaceae}

Parietaria pensylvanica Muhl. ex Willd. (Pennsylvania pellitory) - A; F; RC55

\section{Violaceae}

Viola bicolor Pursh (field pansy) - A; F; KC130

Viola sororia Willd. (common blue violet) - P; F; KC136

\section{Vitaceae}

Parthenocissus quinquefolia (L.) Planch. (Virginia creeper) - P; V; AP112

Vitis vulpina L. (frost grape) - P; V; RC68, RC79

\section{MONOCOTS}

Amaryllidaceae

${ }^{\star}$ Allium vineale L. (wild garlic) - P; F; KC158

Nothoscordum bivalve (L.) Britton (crowpoison) - P; F; KC133

\section{Asparagaceae}

*Muscari botryoides (L.) Mill. (common grape hyacinth) - P; F; KC129

\section{Commelinaceae}

${ }^{*}$ Commelina communis L. (Asiatic dayflower) - A; F; KC81

Commelina erecta L. (whitemouth dayflower) - P; F; AK2, AP101, RC72

Tradescantia ohiensis Raf. (bluejacket) - P; F; RC70, AP111

\section{Cyperaceae}

Carex muehlenbergii Schkuhr ex Willd. (Muhlenberg's sedge) - P; G; AP87, RC60

Carex retroflexa Muhl. ex Willd. (reflexed sedge) - P; G; GC1305

Cyperus echinatus (L.) Alph. Wood (globe flatsedge) - P; G; KC144

Cyperus lupulinus (Spreng.) Marcks (Great Plains flatsedge) - P; G; AP78, RC51

Cyperus reflexus Vahl (bentawn flat sedge) - P; G; AP59, AP117

Cyperus squarrosus L. (bearded flat sedge) - A; G; AP61

Lipocarpha drummondii (Nees) G.C. Tucker (Drummond's halfchaff sedge) - A; G; AP118

Scleria ciliata Michx. (fringed nutrush) - P; G; GC1277

\section{Iridaceae}

Sisyrinchium angustifolium Mill. (narrowleaf blue-eyed grass) - P; F; KC159

\section{Juncaceae}

Juncus coriaceus Mack. (leathery rush) - P; G; AP79

Juncus interior Wiegand (inland rush) - P; G; GC1303

Juncus marginatus Rostk. (grassleaf rush) - P; G; AK6, RC61, AP60

\section{Poaceae}

Andropogon gerardii Vitman (big bluestem) - P; G; CC60

Andropogon ternarius Michx. (splitbeard bluestem) - P; G; GC1287, GC1318

Aristida oligantha Michx. (prairie threeawn) - A; G; CC57

Bothriochloa laguroides (DC.) Herter (silver beardgrass) - P; G; KC143, GC1276 
Bouteloua curtipendula (Michx.) Torr. (sideoats gramma) - P; G; KC64

Bouteloua dactyloides (Nutt.) Columbus (buffalograss) - P; G; AP83

Bouteloua hirsuta Lag. (hairy grama) - P; G; KC63

*Bromus catharticus Vahl (rescuegrass) - A; G; GC1310, RC50

${ }^{\star}$ Bromus commutatus Schrad. (meadow brome) - A; G; RC62

*Bromus japonicus Thunb. ex Murray (Japanese brome) - A; G; AP77

Bromus pubescens Muhl. ex Willd. (hairy woodland brome) - P; G; RC54

${ }^{*}$ Bromus tectorum L. (cheatgrass) - A; G; GC1309

Cenchrus incertus M.A. Curtis (field sandbur) - P; G; KC121, AP116

Chasmanthium latifolium (Michx.) H.O. Yates (Indian woodoats) - P; G; AP114

Chloris verticillata Nutt. (tumble windmill grass) - P; G; SD68

Coelorachis cylindrica (Michx.) Nash (cylinder jointtail grass) - P; G; AP81

Coleataenia anceps (Michx.) Soreng (beaked panicgrass) - P; G; KC36

*Cynodon dactylon (L.) Pers. (Bermudagrass) - P; G; RC49, KC160

*Dactylis glomerata L. (orchardgrass) - P; G; AP82

Dichanthelium acuminatum (Sw.) Gould \& C.A. Clark (tapered rosette grass) - P; G; KC74, AP115, AP52

Dichanthelium oligosanthes (Schult.) Gould (Heller's rosette grass) - P; G; GC1311, KC60

Dichanthelium scoparium (Lam.) Gould (velvet panicum) - P; G; SD70

Digitaria ciliaris (Retz.) Koeler (southern crabgrass) - A; G; KC111

Echinochloa muricata (P. Beauv.) Fernald (rough barnyardgrass) - A; G; KC104

*Eleusine indica (L.) Gaertn. (Indian goosegrass) - A; G; KC146

Elymus virginicus L. (Virginia wildrye) - P; G; AK4, AP72

Eragrostis capillaris (L.) Nees (lace grass) - A; G; KC73

Eragrostis secundiflora J. Presl (red lovegrass) - P; G; KC53

Eragrostis spectabilis (Pursh) Steud. (purple lovegrass) - P; G; CC56

Hordeum pusillum Nutt. (little barley) - A; G; AP70, RC52

Panicum virgatum L. (switchgrass) - P; G; CC61, KC145

Paspalum setaceum Michx. (thin paspalum) - P; G; AP80, KC45

*Phragmites australis (Cav.) Trin. ex Steud. (common reed) - P; G; KC151

*Poa annua L. (annual bluegrass) - A; G; AP55, RC37

*Schedonorus arundinaceus (Shreb.) Dumort. (tall fescue) - P; G; KC156, RC65

Schizachyrium scoparium (Michx.) Nash (little bluestem) - P; G; CC47

*Setaria faberi R.A.W. Herrm. (Japanese bristlegrass) - A; G; AK5, SD61

Sorghastrum nutans (L.) Nash (Indiangrass) - P; G; CC58

*Sorghum halepense (L.) Pers. (Johnsongrass) - P; G; RC71, KC54, AP86

Tridens flavus (L.) Hitchc. (purpletop tridens) - P; G; SD76

*Vulpia myuros (L.) C.C. Gmel. (annual fescue) - A; G; AP85

Vulpia octoflora (Walter) Rydb. (sixweeks fescue) - A; G; GC1312

\section{Smilacaceae}

Smilax bona-nox L. (saw greenbrier) - P; V; AP106

Smilax tamnoides L. (bristly greenbrier) - P; V; RC69 